\title{
Article \\ Planners between the Chairs: How Planners (Do Not) Adapt to Transformative Practices
}

\author{
Frank Othengrafen * and Meike Levin-Keitel
}

Faculty for Spatial Planning, TU Dortmund, 44221 Dortmund, Germany; E-Mails: frank.othengrafen@tu-dortmund.de (F.O.), meike.levin-keitel@tu-dortmund.de (M.L.-K.)

* Corresponding author

Submitted: 15 May 2019 | Accepted: 25 September 2019 | Published: 27 December 2019

\begin{abstract}
Even though the turn to practice is widely accepted in the field of urban planning, the practices of planners are empirically largely unexplored. Looking at the daily routines and practices of urban planners thus allows a deeper insight into what planning is, and how planning practices are related to innovation and transformation. To do so, we start from the assumption that behaviour is a constellation of practices, including certain activities, a set of choices and actions, patterns of behaviour or forms of interaction that is organised in a certain space or context by common understandings and rules. By conducting an online survey among planners in medium-sized German cities, we first identified a wide range of planning practices and activities in general. In a second step, we conducted a statistical cluster analysis resulting in six types of planners: (1) the 'local-specific analysts,' (2) the 'experienced generalists,' (3) the 'reactive pragmatists,' (4) the 'project-oriented planners,' (5) the 'compensatory moderators,' and (6) the 'innovative designers.' Each cluster has specific practices and activities, linked to characteristic value-sets, role interpretations and self-perceptions that might help explain the differences with regard to innovation and transformation. From the identified six groups or clusters of planners, only two clusters more or less consequently aim at innovation, experimentation and new approaches. One cluster is dedicated to collaborative practices whereas traditional practices predominate in three clusters at least, mainly because of legal requirements. This is the result of an increasing 'formalisation' of land-use planning, making planners focus on technical and formal practices, and, at the same time, lead to the reduced 'attention' to and implementation of conceptual approaches or 'necessary' transformative practices, including proactive approaches and strategic coordination with regard to sustainable urban development, but also comprising experiments, real labs or social innovations.
\end{abstract}

\section{Keywords}

cluster analysis; planning practice; role of planners; transformative practices; urban planning

\section{Issue}

This article is part of the issue "Towards Transformative Practice Frameworks: Planners, Professional Agency and Sustainable Urbanism" edited by Nezhapi-Dellé Odeleye (Anglia Ruskin University, UK) and Niamh Murtagh (University College London, UK).

(C) 2019 by the authors; licensee Cogitatio (Lisbon, Portugal). This article is licensed under a Creative Commons Attribution 4.0 International License (CC BY).

\section{Introduction}

Planning is what planners do (Vickers, 1968). However, the practices of planners might differ from city to city or region to region as these practices, routines or patterns of behaviour are shaped in a certain social or spatial context. But how can we identify and describe the practices planners perform in their daily business? Do prac- tices change over time? What moral and ethical values underlie the actions of planners? How do they reflect on their actions? How much autonomy and agency do urban planners actually have in their daily business? Against this background, it is the aim of the article to identify the different practices and attitudes of planners and to systematically reflect on the daily practices and routines of planners to draw conclusions with regard to the self- 
perception of urban planning. Of particular interest is the extent to which practices in general influence the daily routines of planners and the roles of planning underlying these practices.

To do so, we start from the assumption that planning is a constellation of practices, including certain activities, a set of choices and actions, patterns of behaviour or forms of interaction that are organised in a certain space or context by common understandings and rules. Here, we mainly refer to practice theories as developed by Reckwitz (2002), Schatzki (2001, 2002), Shove, Pantzar, and Watson (2012) or Swidler (2001), where practices are defined as "sets of hierarchically organised doings/sayings, tasks and projects" (Schatzki, 2002, p. 73). By focusing on practices as the smallest unit of social analysis, practice theory thus offers a conceptual framework that comprises a certain way of seeing and analysing social phenomena. This approach opens up a new possibility to observe the everyday actions of actors and to adopt a more realistic perspective than other behavioural theories (Reckwitz, 2002).

Applied to urban planning, this means that practices "are thus assemblages of open-ended sets of actions performed by agents who mobilise skills and knowledge, ideas and materials in a more or less conscious way" (Savini, 2019, p. 60; see also Schatzki, 2002). These practices are not only spatially situated, but also have a spaceforming effect (Beauregard, 2013). Planners repeat certain practices frequently and regularly and thus constitute specific 'spatial arrangements' that arise from the interaction of planners with other planners and stakeholders as well as with artefacts (e.g., plans, significant buildings and settlement structures). At the same time, specific spatial and institutional arrangements also influence and shape the practices being practised (e.g., Schatzki, 2016, p. 33).

In this context, it is our aim to analyse how planning practitioners actually work by questioning the foundation of their motivation, their underlying values, the diversity of their approaches and their attitudes towards different forms of practices. However, despite the pervasive interest in the practices of planners that encompasses "ways of talking, rituals, implicit protocols, routines, relational strategies, character traits and virtues" (Mandelbaum, 1996, p. 179; see also Watson, 2002, p. 179), those practices are largely unexplored. The turn to practice is widely accepted in the field of urban planning (Liggett, 1996; Watson, 2002), however, most contributions do not refer to the practice theories mentioned above, and rather see planning practice as a starting point for theory formation in planning research (Zimmermann, 2017). One exemption is the work of Healey (1992), who took a practice perspective in her essay entitled A Planner's Day, describing which activities and knowledge types determine the daily life of a senior planner in an English city. This practice-based approach clearly indicates that it is necessary for the analysis to reintegrate what planners are doing (e.g., technical ex- pertise), why they are performing in a particular way (e.g., moral vision) and how their practices are framed in the organisational setting (e.g., adversarial politics; see, for example, Forester, 1999, 2013; Hoch, 1994; Vigar, 2012).

The complex interrelations and the often hidden and implicit notions between these different dimensions of practices already give an idea of the challenges to translate such an approach in empirical research design: What can be seen as technical expertise in planning-planmaking, place-based decision-taking? What strategies, skills and methods do planners use to fulfil their tasks? (see also Forester, 1993; Howe \& Kaufman, 1979; Schön, $1982,1983)$. How does one ask planners about their ethical orientation-values as underlying implicit assumptions? Which roles do planners assume when performing different planning practices (Lamker, 2016; Vigar, 2012)? What moral and ethical values underlie their actions? How do they reflect on their actions? How does one describe the interface of planning and politics by integrating questions of expertise and values-considering that both work for the common good? All these questions are partly addressed in more recent studies on planning practices (e.g., Beauregard, 2013; Clifford \& Tewdwr-Jones, 2013; Ferm \& Tomaney, 2018; Forester, 2013; Lauria \& Long, 2017). But either these approaches address practices rather accidentally, and not as comprehensively as 'required' in the practical theories mentioned above, or they focus on few planners and their experiences and lack a broader empirical base. This has been our motivation to conduct a survey among urban planners working in medium-sized cities in Germany to be able to: (1) identify and analyse planning practices broadly, and (2) identify ideal types of planners based on the practices and attitudes of urban planners.

When analysing planning practices, it is also necessary to consider the different understandings or interpretations of urban planning, the ways planners make decisions, the ways planners' decisions are legitimised, or the roles of planners in planning processes. Ideally, we can distinguish between more traditional, cooperative and transformative planning understandings and practices. First, there are a number of tasks and 'duties' which urban planning must fulfil, and which lead to legally binding plans and programs, to institutionallyframed tasks within the city administration, to activities based on planners' specific expertise. These somewhat 'traditional' planning practices show a close instrumentalism on goal-specific tasks, means, and outcomes (Savini, Majoor, \& Salet, 2015, p. 296; see also Lauria \& Long, 2017, p. 204). These practices find their expression in activities such as protecting natural resources and certain areas, fulfilling basic and social needs (e.g., affordable housing or healthy living conditions), avoiding socio-spatial polarisation and implementing infrastructure projects. In this understanding, planning is a technical task which is carried out by experts, has a controlling function, and is regulative and intervening (e.g., Savini, 2019, p. 60). 
Second, there are collaborative or communicative planning practices, which are characterised by communication and participation (e.g., Fischler, 2000; Harris, 2002; Healey, 1997, 2003; Innes, 1995; Sager, 2009). Here, planners often act as 'initiators' or 'mediators' to foster cooperation among actors involved in planning processes. The aim is to build consensus between all actors; therefore, power should be distributed amongst the stakeholders such that they are equals in the process. Openness and trust are also crucial for building consensus (Healey, 1997).

Third, more and more transformative practices can be observed. Planning through processes of 'co-creation,' referring to processes where planners, local communities, social associations, civil society actors, enterprises and business associations initiate joint learning processes to develop sustainable perspectives and strategies for the development of the city (e.g., Nevens, Frantzeskaki, Gorissen, \& Loorbach, 2013; Schäpke, Singer-Brodowski, Stelzer, Bergmann, \& Lang, 2015) has become a priority for practitioners and scientists (Savini et al., 2015, p. 296). These emerging practices can be defined as 'experiments,' 'niches,' 'living labs,' or 'social innovations' (Evans, Karvonen, \& Raven, 2016; see also Savini, 2019, p. 59) to stress their transformative potential for a different, more sustainable future (Grin, Rotmans, \& Schot, 2010; Loorbach, Frantzeskaki, \& Avelino, 2017; Rotmans, Kemp, \& van Asselt, 2001). In comparison with more collaborative practices, this approach focuses to a lesser extent on participation and public engagement to implement citizens' knowledge in urban development plans or concepts; the focus is rather on joint learning processes and the shared responsibility for the intended transformation processes. These so-called transformative practices consist of jointly developed images and visions and, at the same time, of strategies and instruments for the implementation, in which the spatial dimension plays a central role (Albrechts, 2016; Levin-Keitel, Mölders, Othengrafen, \& Ibendorf, 2018).

In practice, the different ideal types of planning are to be found next to each other-a strict separation is not possible. However, we can conclude that planners have to work with structural tensions between organisation and spontaneity, control and self-organisation, experiments and routines, legal validity and openness, or intervention and non-intervention (Lauria \& Long, 2017; Savini et al., 2015; Vigar, 2012). This influences how planners arrange their daily practices, how they make their decisions, and which roles they use in planning processes. We can summarise here that:

The tales...from the everyday lives of practicing planners show how the conventional beliefs that separate moral vision, technical expertise and adversarial politics do not adequately explain what planners do....Some identified more closely with the conventions of competent inquiry, while others cared more about political strategy. (Hoch, 1994, p. 321)
This again shows the need to address planning practices from the perspective of the social science oriented practical theories to identify the different practices and attitudes of planners and to reflect systematically on the daily practices and routines of planners to draw conclusions with regard to the self-perception of urban planning.

To analyse how planners deal with these demands and expectations (e.g., organising collective spatial actions and policies or developing a legally binding landuse plan) simultaneously, the article first presents the empirical results of a survey on planners' practices conducted in medium-sized cities between 20,000 and 100,000 inhabitants in Germany (see Section 3). Here, we analyse various sets of practices (fields of action, activities, roles and professional agency) to deepen our understanding of planners' practices, values, norms and routines as well as their role perceptions and their strategic choice of roles. To avoid an overly strong simplification and to cope with the complexity of a practicetheory approach, we first present current practices of planners before interpreting and discussing to what extent planners are already involved in transformative practices. Section 4 then presents a cluster analysis of different types of planners based on the practices and attitudes of urban planners. The last section summarises the results and discusses the roles of planning and planners with regard to planning practices, in particular in the face of transformative planning practices.

\section{Methodology: How to Analyse Planning Practices}

In order to be able to map and analyse the daily practices of planners accordingly, we decided to focus on urban planners working in planning departments in mediumsized cities in Germany. Planners in this survey imply persons working in urban planning departments in mediumsized cities, including urban planning, urban development or regeneration as well as social housing. We assume that the practices and the tasks of planners in medium-sized cities are less specialised than those of planners working in larger cities, offering us the chance to map the entire spectrum of what planning practices encompass. Furthermore, medium-sized towns with a population between 20,000 and 100,000 inhabitants are typical for the German spatial structure and settlement system (Baumgart, 2011, p. 9; BBR, 2001, p. 4). About $42 \%$ of Germany's population lives in mediumsized cities, meaning that they play an important role in spatial development in general (Schmitt, 2010, p. 29).

We opted for a sequential quantitative-qualitative research design. By combining quantitative and qualitative research methods, we not only follow planners' stories and other 'micro-sociological' approaches (e.g., Forester, 1993; Healey, 1992; Hoch, 1994), but also consider and integrate institutional understandings in our analysis (see also Beauregard, 1999; Watson, 2002). In total, we conducted: (1) a quantitative online-survey, 
(2) qualitative expert interviews, and (3) expert workshops or focus group discussions. The online survey took place between 22 May and 4 July 2017 by using an online survey tool. The link to participate in the online survey was sent by email to the planning departments in all medium-sized cities. In cases in which we had the individual email-addresses of planners working in the planning departments, we addressed the survey directly to them. In other cases, the link was sent to the given institutional (collective) email addresses of the planning departments with the request to forward the survey to the relevant colleagues within the respective urban planning departments.

The questionnaire was structured in four parts. The first part was dedicated to planners' fields of action and areas of activity, whereas the second part concentrated on the roles and role perceptions of planners. The third part addressed questions about how urban planners make decisions; the fourth part contained biographical and personal information as well as information on the planning department. In the survey, questions about the personal and institutional values of the planners played a central role. Therefore, we adapted the research design of Schwartz (2012) for our study. Schwartz (2012) works with indirect statements such as: "Thinking up new ideas and being creative is important to him. He likes to do things in his own original way" (Schwartz, 2012, p. 11); Schwartz asks for the interviewees' agreement or rejection of this statement to identify personal values. Our questions on the personal and institutional values of planners working in planning departments in mediumsized cities largely follow this pattern, for example, by starting with the question on one's own understanding of one's role perception to know more about the personal or individual values of planners. Similar to Schwartz (2012), we thus predominantly introduced the questions by using statements such as "It is important to me in my daily practice to...".

In total, 614 urban planners in German medium-sized cities took part in the survey. To analyse the results, we used various statistical-analytical methods (Atteslander, 2000; Diekmann, 2008; Döring \& Bortz, 2016; Völkl \& Korb, 2018). This includes analyses dealing with only one variable (e.g., the determination of frequencies for the fields of action and activities of planners) as well as bivariate analyses that allow the simultaneous analysis of two characteristics (e.g., the correlation between the age or professional experience of planners and their activities; some of the results can be seen in Section 3). Additionally, we conducted multivariate analysis allowing the simultaneous analysis of more than two characteristics (e.g., by carrying out a factor analysis). This also includes a hierarchical cluster analysis that we carried out to identify larger groups of planners that share certain values, which can be distinguished from values of other planners. Cluster analysis as a groupforming method (Bahrenberg, Giese, Mevenkamp, \& Nipper, 2008, p. 259) is a statistical procedure that de- termines homogeneous groups from a large and heterogeneous amount of data. Due to methodological considerations, the Ward method was preferred as a hierarchical method as it led to conclusive data sets allowing us to identify six coherent clusters. The Ward method also has the advantage of creating similarly large clusters as a result of the data consolidation process (Backhaus, Erichson, Plinke, \& Weiber, 2016, pp. 455, 510; Bortz \& Schuster, 2010, p. 465), providing the most consistent results (see Section 4).

Based on the online survey, we further conducted 33 interviews with urban planners (inside view) or politicians (outside view) in eight medium-size cities varying in population size and development, economic development, and spatial location (peripheral or central). The expert interviews contributed to a more differentiated view on planning practices and contributed to explaining unexplained variances in the quantitative data. The interviews took place between 23 April and 1 October 2018. Additionally, we organised two focus group discussions with each of the 10-15 participants in February 2019 to validate and deepen our interpretations of the survey and the cluster analysis. One workshop was held with practising planners of selected medium-sized German cities to enrich our findings with their experiences and their reflections; the second workshop involved scientists from planning departments of German universities to reflect the results theoretically and from different perspectives.

\section{Planners' Practices: An Overview}

To understand the analysed planning practices in its localspecific framing conditions, a few characteristics about the German context have to be mentioned. In Germany, all cities and municipalities have the guaranteed right of local self-government (Art. 28 II of the Basic Law); that means the general competence to undertake all public affairs for their territory, including urban planning and development. Urban planning in Germany, unlike in some other European countries, is not confined to land-use planning, regulating exclusively the use of a certain piece of land. It is rather a function to coordinate all spatially relevant interests, functions, programs and projects. Urban planning in itself has no funds or implementing powers, its task is above all to direct and facilitate the activities of other actors (Blotevogel, Danielzyk, \& Münter, 2014; Commission of the European Communities, 1999; Pahl-Weber \& Henckel, 2008).

\subsection{Various Fields of Action: Planners as Generalists in the Public Realm}

Urban planning is an occupational field with various thematic fields of action, which is also reflected in the daily practices of planners in medium-sized cities. Based on 15 previously selected fields of action, the planners have indicated how frequently they work in the respective field 
of action (see Figure 1). The vast majority of planners 'very often' or 'often' work in the field of 'urban landuse planning' (92\%), followed by the areas of 'housing' (83\%) and 'integrated urban development' (70\%). This is also found in surveys of graduated planners of various planning faculties (e.g., Bornemann et al., 2017; Krüger, 2013; Leschinski-Stechow \& Seitz, 2015). Interestingly, and in contrast to the frequently discussed topics in academia, planners only 'infrequently' or 'never' work in the fields of 'climate change,' 'monument conservation' or 'social urban development.' In addition, it becomes clear that the majority of respondents are active in all 15 action fields determined in the questionnaire. Less than $10 \%$ of the planners work in ten or fewer action fields (Othengrafen, Levin-Keitel, \& Breier, 2019). This allows the assumption that planners, especially in mediumsized towns, are 'generalists' working in many different fields of action (Friedmann, 1996).

The naming of 'urban land-use planning,' 'housing' and 'integrated urban development' as central areas or action fields can, on the one side, be explained through the broad scope of the urban planning system in Germany. Additionally, this can also be understood as an expression of the discussions and challenges that plan- ners currently have to cope with (e.g., affordable housing, the legal status of development plans, etc.). On the other hand, the normative orientation of urban planning also plays a major role. Here, urban planning as a predominantly municipal task should contribute to implement welfare state objectives (see also Evans, 1993; Low, 1991, p. 26; Vigar, 2012, p. 362). This understanding of planning as 'the guardian' of the common good is associated with the corresponding core tasks (i.e., provision of affordable housing, etc.), which are also largely defined and regulated in the German Building Code (Levin-Keitel, Othengrafen, \& Behrend, 2019).

\subsection{Planners' Activities: A Colourful Bouquet of Activities between Plan-Making and Moderating Exchange}

In addition to the fields of action, it is also relevant to know what exactly planners do-in other words, which activities they pursue. Do they, for instance, draw up plans, negotiate with investors, represent environmental concerns, or do they try to find consensus between various actors with different or conflicting interests? Planning theories deliver all kinds of different activities

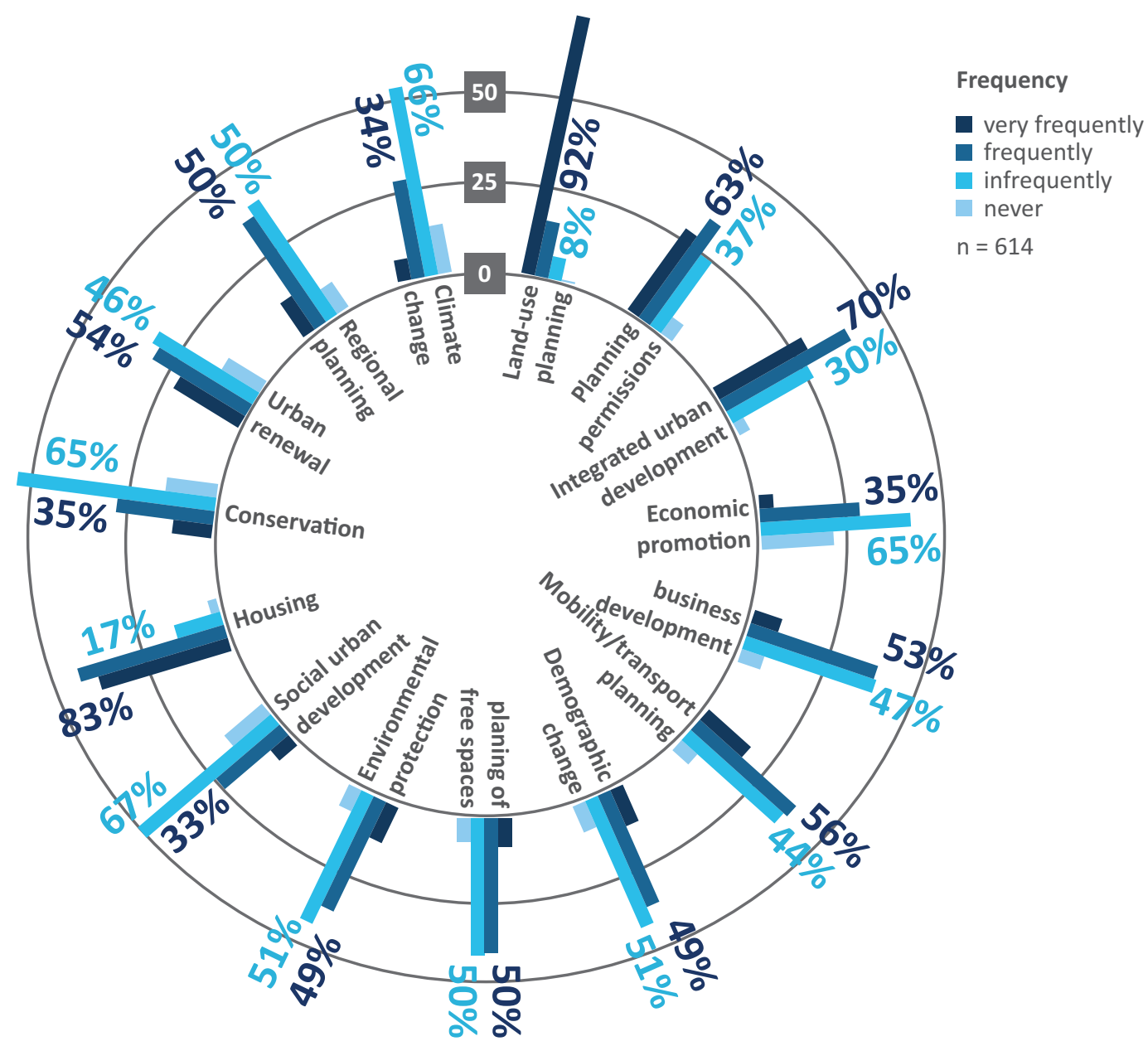

Figure 1. Fields of action. The answers 'very frequently' and 'frequently' as well as 'infrequently' and 'never' are summarised in the respective percentages. 
depending on the theoretical perspectives they follow, and often theoretical approaches are anchored in such activities as the communicative turn in organising participation, the just city in representing arguments of unrepresented groups, the rational-technical paradigm in making technical plans. But to what extent is this reflected in planning practice? The participants of the survey received various statements relating to different activities and were asked to indicate how often they pursue these activities in their daily work (see Figure 2). For example, a high proportion of the planners (69.8\%) agreed with the statement "I draw up legally binding plans," which is typical for urban land-use planning. In addition, coordinating and mediating tasks are a central area of planning, as the activity "I bring together different (conflicting) interests and contribute to the reconciliation of interests" (73.2\%) shows. The activities "I create strategic planning concepts such as climate adaptation concepts or mobility master plans" (45.3\%) and "I decide on building applications" (35.3\%), on the other hand, are of lesser importance. The latter in particular shows again that urban planning in Germany is not only restricted to land-use planning but concentrates more on the strategic coordination of different interests, objectives and land uses.
When comparing the activities with the respective professional position, however, differences also become obvious (see Figure 3): In general, all respondents state that coordination is an important activity in their daily practice, but it is most of all planners at higher management levels exercising this activity (64.4\%). On the other hand, the preparation of legally binding plans predominantly seems to be a task of planners at the project level (49.1\%). The preparation of political decisions, in contrast, is again a task that planners at the management level perform more frequently (67.1\%). In summary, respondents in management positions tend to take on more coordinating, advisory and intermediary activities. Project managers are more likely to be involved in technical and specific planning tasks (Othengrafen et al., 2019), a finding rarely discussed in theoretical reflections on planning practices so far.

\subsection{Individual and Professional Role Perceptions}

In their daily practices, planners take on very different roles to 'get things done.' Many of these role assignments are described in planning theories representing different planning approaches (Fox-Rogers \& Murphy,
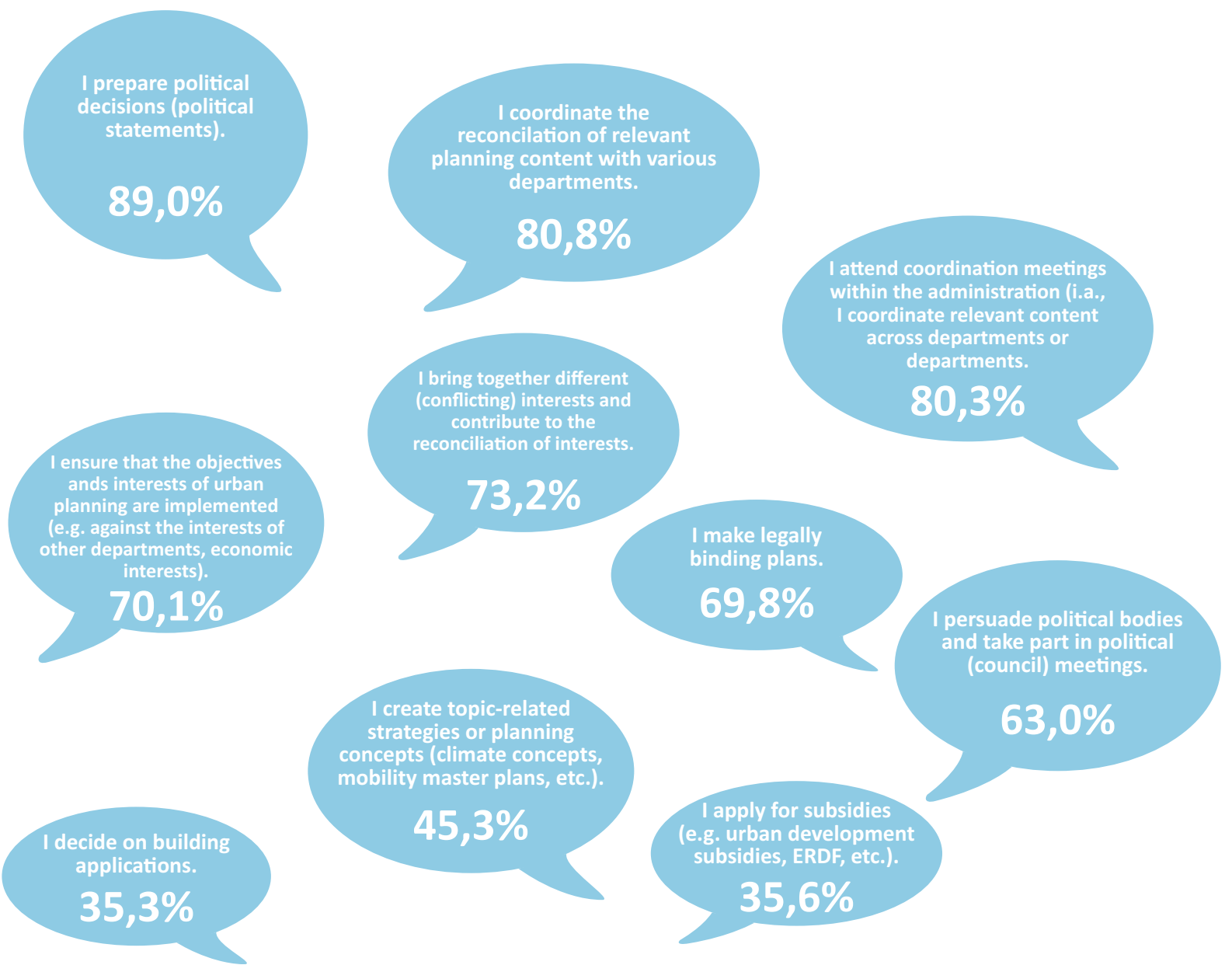

Figure 2. Planners' activities. The percentages in the figure indicate how often participants chose 'very frequently' and 'frequently.' 
I coordinate the reconcilation of planning/spatial content with various departments.
I make legally binding plans

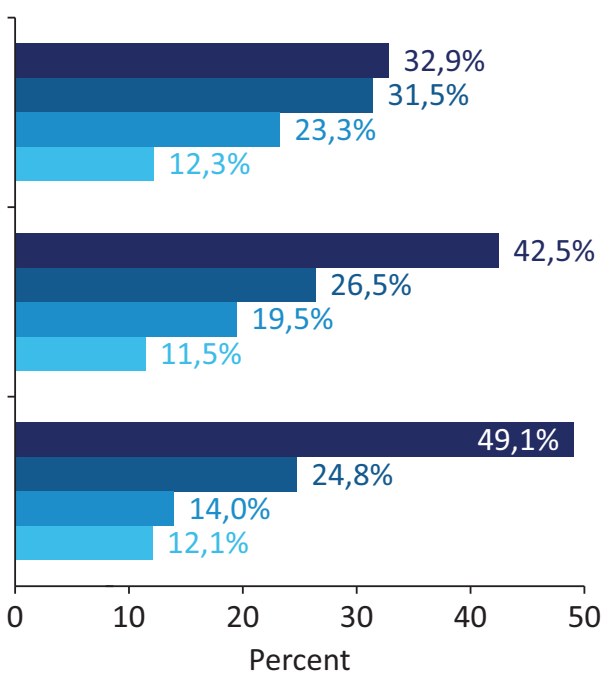

\author{
Frequency \\ very frequently $\mathbf{a}$ frequently $\square$ infrequently $\square$ never
}

$n=473$

Figure 3. Planners' activities along the respective professional position. Note: $\mathrm{N}=473$.

2015, pp. 2-3; Knox \& Masilola, 1990, p. 20; McGuirk, 1995). They serve as theoretical lenses for different approaches to planning, the underlying perceptions of problems (i.e., what is perceived and evaluated as a problem), the comparability of various planning activities and the interaction with other actors (Albrechts, 1991; Campbell \& Marshall, 2002; Fox-Rogers \& Murphy, 2015; Lamker, 2016, p. 100). Role models can generally refer to institutional as well as individual role perceptions. The institutional understanding describes a general perspective on the role of urban planning as an institution whereas the individual role understanding covers the personal role attributions and priorities of the planners themselves. Urban planning as a discipline is thus assigned by a multitude of roles by planners at both individual and institutional levels.

The roles of urban planning as an institution (see Figure 4) include the control of spatial development (95.3\%), the decision preparation of political processes (90\%), the process-coordinating task (85\%) as well as planning as a content-related task (80\%). Less frequently mentioned is the representation of the interests of disadvantaged groups (45\%). It is obvious that urban planning cannot be reduced to one or another role perception, and therefore the approaches in planning theory reducing these complex interplays in urban planning need to be assigned to its limitations. The respective roles must, therefore, be assessed depending on the situation and, in a first step, merely show the spectrum and variety of roles.

Individual understandings of roles show a similar picture (see Figure 5), where planners wear different hats, feeling responsible, among others, for a compensatory moderation (95.3\%), for steering (92.2\%) and for the implementation ( $88.5 \%$ ) of spatial development, and for political consultancy (79.6\%). There is less support for interpreting the role as an innovator $(74.8 \%)$ or as an initiator $(74.8 \%)$ and much less support to act as an advocate for the interests of disadvantaged groups $(47.6 \%)$ or for preservation issues (11.9\%). In comparison, many institutional role understandings can be found on an individual level, ranging from a more technical role on the one side to a more political role on the other (see also Lauria \& Long, 2017). It becomes clear that planners in their daily practice have to deal with a multitude of roles that are mutually exclusive in individual cases (e.g., a moderating activity excludes a simultaneous technical role). However, it can be summarised that coordination, moderation, political consultancy and the control of urban development seem to be the most prominent roles that planners perceive. This has been confirmed by the practitioners in the focus group discussions where the planners explained that urban planning as a department is regarded by both planners (internal view) and politicians (external view) as one of the central departments within medium-sized cities that is given great importance for the future development of the city. This might help to explain the more strategic and, at the same time, communicative roles that planners perceive in German mediumsized cities (see also Blotevogel et al., 2014, p. 105).

\section{Planners and Planning Practices: Six Ideal Types of Planners}

The previous section has presented the range of planning practices and activities in general. However, it is still un- 
COGITATIO

I see urban planning as a service

provider for political concerns.

I understand urban planning as a

service provider for the economy

I understand urban planning as a service

provider for the concerns of citizens.

Urban planning takes over the

steering os spatial development.

I see urban planning as representing

the interests of disadvantaged groups.

$45 \%$

I understand urban planning as the prepara-

ton of decisions for political processes.

$90 \%$

I understand urban planning mainly as

a technical task.

$80 \%$

I see urban planning mainly as a

process coordination task.

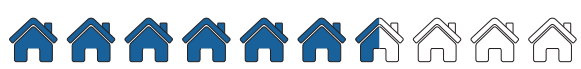

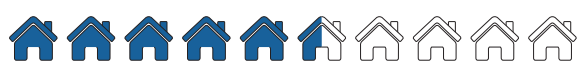

소솟ㅅㅅㅅㅗํํํำ

솟ㅅㅅㅅㅅㅅ소송

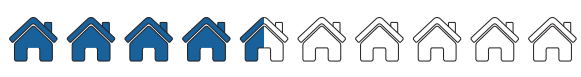

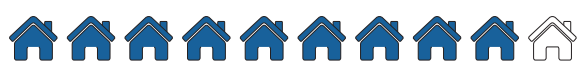

소소솟ํํำ

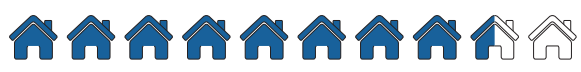

Figure 4. Professional role understandings.

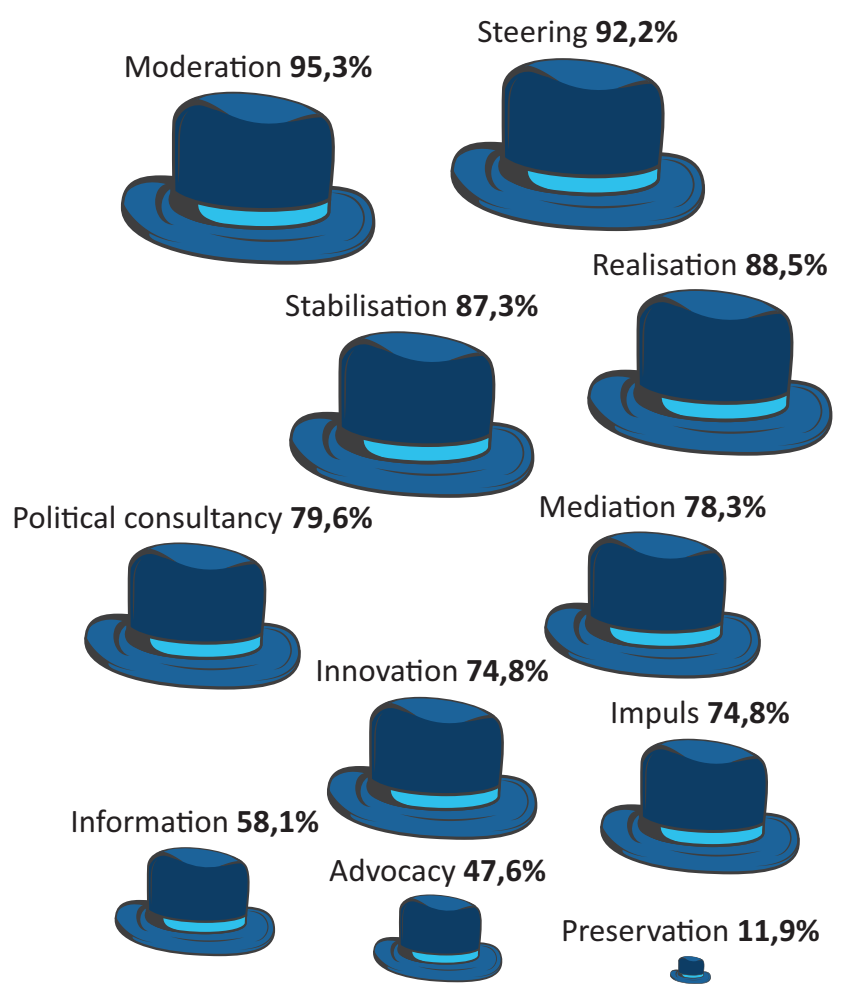

Figure 5. Individual role perceptions. Note: $\mathrm{N}=511$.

Urban Planning, 2019, Volume 4, Issue 4, Pages 111-125

118 
clear to what extent individual practices, activities and values differ from one another. Are there empirically verifiable profiles of planners that differ from each other? Are these values, perceptions and attitudes only related to the individual level or is it also possible to identify larger groups of planners that commonly share certain values and that can be distinguished from each other? Moreover, to what extent do traditional, collaborative or transformative practices become visible in the completion of tasks or in the underlying perception of planning in these larger groups? For this purpose, a hierarchical cluster analysis was carried out (see Section 2), identifying six coherent clusters.

Looking at the six clusters, it is noticeable that cluster 2 (the 'experienced generalists') and cluster 6 (the 'innovative designers') share many characteristics. This refers to the dominant age groups (from 46 to 55 and over 56 years), the longstanding professional experience, and the high proportion of planners working in management positions (e.g., as head of the urban planning department; see Table 1). However, with regard to planning practices and values, the two clusters differ significantly: The experienced generalists most frequently (1) ensure that the aims of urban planning are implemented and (2) negotiate regularly with investors as part of their daily work. Highly relevant for the respondents are also the analysis and evaluation of data as well as the political consultancy, i.e., to provide comprehensive advice to politicians. The planners in this cluster favour strategic and spatial control through concepts and plans (see Figure 4), which can be interpreted as an expression of the German planning system (see Section 3). The implementation of individual projects is, compared to other clusters, less important to them. The innovative designers, on the contrary, develop strategies (e.g., for climate adaptation) and apply for funding. In comparison to the experienced generalist and the other clusters, planners are most often concerned with realising concrete projects ( $95 \%$ consent) and valuing the importance of target group-specific communication. Moreover, all respondents agree that they understand their role as initiators ( $100 \%$ consent); another $90 \%$ think that it is important to develop and implement new approaches and instruments. The members of this cluster seem to be very open to transformative practices and the experiments, innovations and formats associated with them.

Compared to these two clusters, it is evident in cluster 4 (the 'project-oriented planner') and cluster 5 (the 'compensatory moderators') that the majority of planners here is under 35 years of age or between 36 and 45 years old. Additionally, cluster 5 is the only cluster with a female majority (see Table 1). With regard to the activities and role perceptions, the project-based plannerssimilarly to the other clusters-draw up legally binding plans but they are also frequently involved in preparing information for the public. Exceptional for the planners in this cluster is their focus on the implementation of projects and plans, which all members of this cluster agree with (100\% consent). They do not see themselves completely as innovators or initiators, but with their general openness to new and innovative approaches or methods they clearly tend towards transformative planning practices. The compensatory moderators, compared to the other clusters, most frequently prepare information for the public. Additionally, they very often bring different interests together and try to balance and reconcile different and sometimes conflicting interests. The vast majority of the planners in cluster 5 find it important to provide comprehensive policy advice and to communicate in a target-group-specific manner. The focus here is clearly on communication, coordination and the balance of different interests (see Figure 2 for the importance of coordination)-all respondents agree that planning should be understood as a process-coordinating task ( $100 \%$ consent). New, experimental participation approaches are applied if these formats seem to be purposeful. These are clearly collaborating practices (see Section 1); however, it is striking that coordination and consideration are largely related to the legally defined objectives of urban planning.

The planners in cluster 1 (the 'local-specific analysts') are involved in a wide variety of activities, although they do not stand out particularly in any of the relevant areas. Above all, they draw up legally binding plans and take part in internal coordination meetings with other municipal departments (see Figure 4). This again shows the importance of urban planning departments within the city administration. The perception of planning roles, however, clearly shows that the collection and evaluation of data are particularly important to them (see Figure 5). Here, planning seems to be understood as a technical task that is carried out by experts, which seems to be the classic self-image of planning in Germany (see Section 3). Innovative approaches and new impulses are much less frequently represented than in other clusters. This seems to be similar in cluster 3 (the 'reactive pragmatists'). Here, planners are also involved in processes of drawing-up legally binding plans; additionally, they contribute to the implementation of planning tasks, bring (conflicting) interests together and prepare information for the public. In comparison to the local-specific analysts and other planners, they tend to have little or no involvement in committee work or external representation, e.g., negotiating with investors. This is not surprising as the majority of the planners in this cluster work at the project level (see Figure 3 and Table 1). The planners see their own role mainly in realising local land-use plans or related activities and advising politicians. Compared to other clusters, the development and use of new instruments and practices are much less favoured. On the contrary, this cluster has by far the largest number of planners (almost 40\%) who wish to maintain the status quo. It becomes clear that traditional planning practices-i.e., the use of existing instruments-are in the foreground to preserve the status quo and to deal with planning tasks within the framework of the given political-administrative structures. 
Table 1. The six clusters in a nutshell.

\begin{tabular}{|c|c|c|c|c|c|c|}
\hline & $\begin{array}{l}\text { Cluster 1: } \\
\text { Local-specific } \\
\text { analysts (17\%) }\end{array}$ & $\begin{array}{l}\text { Cluster 2: } \\
\text { Experienced } \\
\text { generalists (17\%) }\end{array}$ & $\begin{array}{l}\text { Cluster 3: } \\
\text { Reactive } \\
\text { pragmatists (22\%) }\end{array}$ & $\begin{array}{l}\text { Cluster 4: } \\
\text { Project-based } \\
\text { planners (13\%) }\end{array}$ & $\begin{array}{l}\text { Cluster 5: } \\
\text { Compensatory } \\
\text { moderators (19\%) }\end{array}$ & $\begin{array}{l}\text { Cluster 6: } \\
\text { Innovative } \\
\text { designers (12\%) }\end{array}$ \\
\hline Gender & $64 \%$ male & $58 \%$ male & $60 \%$ male & $64 \%$ male & $51 \%$ female & $54 \%$ male* \\
\hline$\overline{\text { Age }}$ & $\begin{array}{l}<35: 17 \% \\
36-45: 29 \% \\
46-55: 20 \% \\
>56: 34 \%\end{array}$ & $\begin{array}{l}<35: 12 \% \\
36-45: 23 \% \\
46-55: 45 \% \\
>56: 21\end{array}$ & $\begin{array}{l}<35: 21 \% \\
36-45: 20 \% \\
46-55: 33 \% \\
>56: 27 \% * *\end{array}$ & $\begin{array}{l}<35: 46 \% \\
36-45: 12 \% \\
46-55: 21 \% \\
>56: 21 \%\end{array}$ & $\begin{array}{l}<35: 31 \% \\
36-45: 20 \% \\
46-55: 28 \% \\
>56: 21 \%\end{array}$ & $\begin{array}{l}<35: 22 \% \\
36-45: 15 \% \\
46-55: 35 \% \\
>56: 28 \%\end{array}$ \\
\hline Position & $\begin{array}{l}\text { 30\%: Head of department } \\
\text { 25\%: Team management } \\
\text { 45\%: Project level }\end{array}$ & $\begin{array}{l}\text { 48\%: Head of department } \\
\text { 28\%: Team management } \\
\text { 24\%: Project level }\end{array}$ & $\begin{array}{l}\text { 20\%: Head of department } \\
\text { 20\%: Team management } \\
\text { 60\%: Project level }\end{array}$ & $\begin{array}{l}\text { 28\%: Head of department } \\
\text { 22\%: Team management } \\
\text { 50\%: Project level }\end{array}$ & $\begin{array}{l}\text { 25\%: Head of department } \\
\text { 22\%: Team management } \\
\text { 53\%: Project level }\end{array}$ & $\begin{array}{l}\text { 43\%: Head of department } \\
\text { 35\%: Team management } \\
\text { 22\%: Project level }\end{array}$ \\
\hline Education & $\begin{array}{l}\text { 53\%: Planning } \\
\text { 2\%: Geogr. } \\
\text { 12\%: Civ. Eng. } \\
\text { 20\%: Architect. } \\
\text { 13\%: Others }\end{array}$ & $\begin{array}{l}\text { 56\%: Planning } \\
\text { 4\%: Geogr. } \\
\text { 4\%: Civ. Eng. } \\
\text { 28\%: Architect. } \\
\text { 8\%: Others }\end{array}$ & $\begin{array}{l}\text { 51\%: Planning } \\
\text { 3\%: Geogr. } \\
\text { 6\%: Civ. Eng. } \\
\text { 26\%: Architect. } \\
\text { 14\%: Others }\end{array}$ & $\begin{array}{l}\text { 50\%: Planning } \\
\text { 12\%: Geogr. } \\
0 \% \text { : Civ. Eng. } \\
\text { 23\%: Architect. } \\
\text { 15\%: Others }\end{array}$ & $\begin{array}{l}\text { 54\%: Planning } \\
\text { 8\%: Geogr. } \\
\text { 3\%: Civ. Eng. } \\
\text { 26\%: Architect. } \\
\text { 9\%: Others }\end{array}$ & $\begin{array}{l}\text { 51\%: Planning } \\
\text { 4\%: Geogr. } \\
\text { 2\%: Civ. Eng. } \\
\text { 26\%: Architect. } \\
\text { 17\%: Others }\end{array}$ \\
\hline $\begin{array}{l}\text { Planning } \\
\text { is about... }\end{array}$ & $\begin{array}{l}\text { Data collection and } \\
\text { analysis } \\
\text { Making legally binding } \\
\text { plans }\end{array}$ & $\begin{array}{l}\text { Strategic and spatial } \\
\text { control through } \\
\text { plans and concepts } \\
\text { Data analysis policy } \\
\text { advice }\end{array}$ & $\begin{array}{l}\text { Making legally binding } \\
\text { plans } \\
\text { Balancing conflicting } \\
\text { interests } \\
\text { Maintaining the } \\
\text { status quo }\end{array}$ & $\begin{array}{l}\text { Implementation } \\
\text { (100\% consent) } \\
\text { Making legally binding } \\
\text { plans }\end{array}$ & $\begin{array}{l}\text { Process-coordination } \\
\text { (100\% consent) } \\
\text { Balancing conflicting } \\
\text { interests } \\
\text { Target-group specific } \\
\text { communication } \\
\text { Policy advice }\end{array}$ & $\begin{array}{l}\text { Implementation } \\
\text { (95\% consent) } \\
\text { Initiating new ideas } \\
\text { and concepts } \\
\text { ( } 100 \% \text { consent) } \\
\text { Innovation ( } 90 \% \text { consent) } \\
\text { Target-group specific } \\
\text { communication }\end{array}$ \\
\hline
\end{tabular}

Notes: * Corresponds approximately to the distribution of the total survey ( $56 \%$ male respondents); ${ }^{* *}$ This corresponds almost to the distribution of the overall survey. 
We can conclude that the clusters show many similarities in terms of action fields, activities and the underlying perceptions of planning. However, there are also recognisable differences, particularly with regard to the perception of traditional, collaborative or transformative practices (see Figure 6). In general, in most clusters, traditional planning practices are predominant, mainly due to legal requirements. In particular, planners in clusters 1 , 2 , and 3 , and to a lesser extent in cluster 4 , are more concerned about traditional practices, referring to technocratic planning models focusing on goal-specific tasks, means, and outcomes.

Obviously, there is not much interest or scope for the application and further development of transformative practices in the daily practice of planners working in planning departments in German medium-sized cities. However, why is that? In the interviews and in the focus group discussion with the practitioners, urban planners explained that they are supposed to ensure that the formal planning processes procedurally continue in a legally correct manner and that the planning outcomes are legally correct. However, this 'formalisation' of urban land-use planning, in contrast, consequently leads to reduced 'attention' as well as the implementation of conceptual approaches or transformative practices, including proactive approaches and strategic coordination with regard to sustainable urban development, but also comprising experiments, real labs or social innovations. This is also reflected in the practices of cluster 5 . Although the practices have a clear focus on collaboration and communication, they nevertheless are closely related to legal procedures. However, planners belonging to clusters 4 and 6 are very open for innovation and thus more willing to allow experiments and new solutions in their daily practices. However, it is important to notice that the clusters do not compete with each other. On the contrary, the focus group discussions with practitioners have shown that all types of planners are needed to fulfil all the relevant tasks urban planning has to deal with (e.g., the planner who initiates experiments and innovations and the planner who develops legally binding plans).

\section{Conclusion}

As we have shown, the differentiated and empiricallybased consideration of planning practices and activities has so far been rather vague in planning sciences or has focused on specific individual cases of planners. A more consistent consideration of practices seems necessary in order to better understand planning as a profession. By focusing on practices as the smallest unit of social analysis, practice theory offers us a conceptual framework to analyse the practices and routines of urban planners, their expertise and activities, their values and moral considerations and the institutional context in which planning is embedded. This was impressively confirmed when conducting the survey, the cluster analysis and the expert interviews which, taken together, have enabled us to identify and analyse planning practices broadly and to identify ideal types of planners based on the observed practices and attitudes.

The identified practices, fields of action and activities may not be completely new and do not come completely unexpected, but they allow a more differentiated picture of urban planning as a profession, and until now have not been considered or represented in planning theory. This also refers to the six identified types of planners, which can also be found in a similar manner in international studies on planners, planners' roles or values. However, the cluster analysis has empirically shown that each of the six clusters has its own specific practices and activities, linked to characteristic value-sets, routines and self-perceptions. It also indicates that some activities and routines are perceived by various clusters at the same time, but might be interpreted or valued differently. Additionally, the cluster analysis shows that planners, i.e., planners, geographers, architects or others working in the urban planning department of mediumsized cities in Germany are socialised by practices and only to a lesser extent by their profession.

Our research has also revealed that traditional planning practices are still prevalent or have recently been used to a greater extent again. Traditional practices pre-

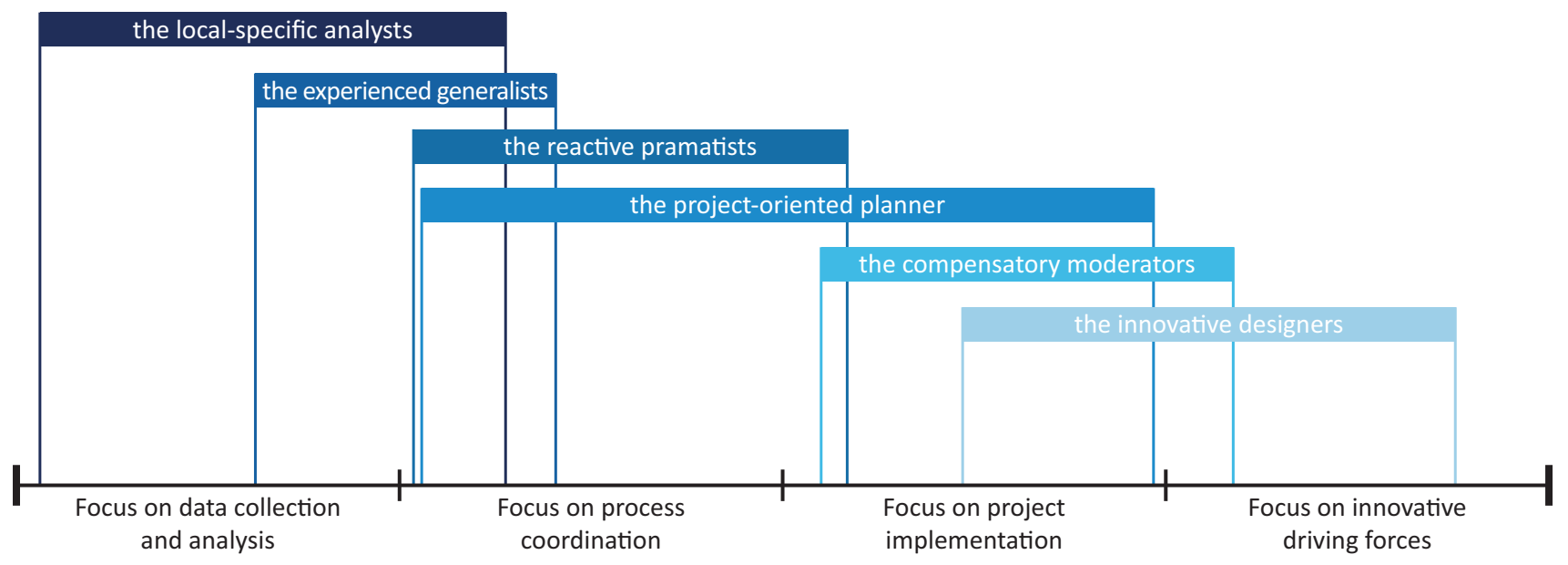

Figure 6. Analysing planning practices: Planners between data analysis and innovation. 
dominate in three clusters at least; one cluster is dedicated to collaborative practices and only two clusters more or less consequently aim at innovation, experimentation and new approaches. One possible interpretation would be that both institutional and individual practices, routines and habits change very slowly. With regard to institutional practices, this might have its roots in the fact that urban planning as a public task is embedded in the political-administrative system, where both substantial and procedural legal requirements have already been laid down, determining the scope of the planning practices at the local level. Additionally, we can at least in Germany observe an increasing 'formalisation' of landuse planning in the last years, making planners focus on technical and formal practices to ensure that plans are adopted in a legally secure manner so that claims by other actors (e.g., with regard to building permits or the construction of wind turbines) can be rejected on the basis of the plans. Subsequently, the original task of a "visionary and holistic spatial design" (Zlonicky, 2009) and the 'innovation function' of planning is only fulfilled to a limited extent in the daily practices of planners. Planners thus seem to sit between the chairs when trying to implement innovative or transformative practices, including new solutions, experiments, or urban labs. Obviously, planners need new 'guiding principles' or 'ethical landmarks' to promote their practices and actions in the on-going social, economic, technological, but also spatial transformation processes (Krau, 2014, p. 320) to be able to guarantee proactive and strategic coordination in terms of sustainable urban development.

\section{Acknowledgments}

This work was supported by the Deutsche Forschungsgemeinschaft (DFG) through grant OT 468/3-1 (project number 60470360). We further acknowledge financial support by DFG and TU Dortmund within the funding programme Open Access Publishing. We also would like to thank our colleague Dominique Charlotte Breier from Leibniz Universität Hannover for carrying out the cluster analysis. Furthermore, we would like to thank the anonymous reviewers and the editors for their valuable comments on the previous version of the article.

\section{Conflict of Interests}

The authors declare no conflict of interests.

\section{References}

Albrechts, L. (2016). Strategic planning as governance of long-lasting transformative practices. In G. Concilio \& F. Rizzo (Eds.), Human smart cities. Urban and landscape perspectives (pp. 3-20). Cham: Springer.

Albrechts, L. (1991). Changing roles and positions of planners. Urban Studies, 28(1), 123-137. https://doi.org/ $10.1080 / 00420989120080081$
Atteslander, P. (2000). Methoden der empirischen Sozialforschung [Methods of empirical social research]. Berlin: Walter de Gruyter.

Backhaus, K., Erichson, B., Plinke, W., \& Weiber, R. (2016). Multivariate Analyseverfahren. Eine anwendungsbasierte Einführung [Multivariate analysis methods. An application-based introduction]. Berlin and Heidelberg: Springer.

Bahrenberg, G., Giese, E., Mevenkamp, N., \& Nipper, J. (2008). Statistische Methoden in der Geographie Band 2: Multivariate Statistik [Statistical methods in geography volume 2: Multivariate statistics]. Berlin and Stuttgart: Gebrüder Borntraeger Verlagsbuchhandlung.

Baumgart, S. (2011). Aktuelle Herausforderungen für Mittelstädte: Eine Einführung [Current challenges for medium-sized cities: An introduction]. In S. Baumgart, N. Overhageböck, \& A. Rüdiger (Eds.), Eigenart als Chance? Strategische Positionierungen von Mittelstädten [Peculiarity as a chance? Strategic positioning of medium-sized cities] (pp. 7-18). Berlin: LIT.

BBR. (Ed.). (2001). Spatial development and planning in Germany. Bonn: Federal Office for Building and Regional Planning.

Beauregard, R. (1999). Writing the planner. Journal of Planning Education and Research, 18(2), 93-101.

Beauregard, R. (2013). The neglected places of practice. Planning Theory \& Practice, 14(1), 8-19.

Blotevogel, H.-H., Danielzyk, R., \& Münter, A. (2014). Spatial planning in Germany: Institutional inertia and new challenges. In M. Reimer, P. Getimis, \& H.-H. Blotevogel (Eds.), Spatial planning systems and practices in Europe. A comparative perspective on continuity and changes (pp. 83-108). London: Routledge.

Bornemann, L., Gerloff, S., Konieczek-Woger, M., Köppel, J., Schmütz, I., Timm, M., \& Wilke, H. (2017). Stadtplanung heute-Stadtplanung morgen. Eine Berufsfeldanalyse [Urban planning today-Urban planning tomorrow. An occupational field analysis] (Working Paper No. 81). Berlin: Department of Urban and Regional Planning, School of Planning Building Environment, TU Berlin.

Bortz, J., \& Schuster, C. (2010). Statistik für Human- und Sozialwissenschaftler [Statistics for human and social scientists]. Berlin and Heidelberg: Springer.

Campbell, H., \& Marshall, R. (2002). Values and professional identities in planning practice. In P. Allmendinger \& M. Tewdwr-Jones (Eds.), Planning futures: New directions for planning theory (pp. 93-109). London and New York, NY: Psychology Press.

Clifford, B., \& Tewdwr-Jones, M. (2013). The collaborating planner? Practitioners in the neoliberal age. Bristol: Bristol University Press.

Commission of the European Communities. (1999). The EU compendium of spatial planning systems and policies: Germany. Luxembourg: Office for Official Publications of the European Communities. 
Diekmann, A. (2008). Empirische Sozialforschung: Grundlagen, Methoden, Anwendungen [Empirical social research: Basics, methods, applications]. Reinbek: Rowohlt.

Döring, N., \& Bortz, J. (2016). Forschungsmethoden und Evaluation in den Sozial- und Humanwissenschaften [Research methods and evaluation in the social sciences and humanities]. Berlin and Heidelberg: Springer.

Evans, J., Karvonen, A., \& Raven, R. (2016). The experimental city. Abingdon: Routledge.

Evans, B. (1993). Why we no longer need a town planning profession. Planning Practice and Research, 8(1), 9-15. https://doi.org/10.1080/02697459308722865

Ferm, J., \& Tomaney, J. (Eds.). (2018). Planning practice. Critical perspectives from the UK. London: Routledge.

Fischler, R. (2000). Communicative planning theory. A Foucauldian assessment. Journal of Planning Education and Research, 19(4), 358-368.

Forester, J. (1999). The deliberative practitioner. Encouraging participatory planning processes. Cambridge, MA: MIT Press.

Forester, J. (1993). Practice stories: The priority of practical judgement. In F. Fischer \& J. Forester (Eds.), The argumentative turn in policy analysis and planning (pp. 187-209). Durham, NC: Duke University Press.

Forester, J. (2013). On the theory and practice of critical pragmatism: Deliberative practice and creative negotiations. Planning Theory, 12(1), 5-22.

Fox-Rogers, L., \& Murphy, E. (2015). Self-perceptions of the role of the planner. Environment and Planning $B$, 43(1), 74-92. https://doi.org/10.1177/026581351 5603860

Friedmann, J. (1996). The core curriculum in planning revisited. Journal of Planning Education and Research, 15(2), 89-104.

Grin, J., Rotmans, J., \& Schot, J. (2010). Transitions to sustainable development. New directions in the study of long term transformative change. New York, NY: Routledge.

Harris, N. (2002). Collaborative planning. From theoretical foundations to practice forms. In P. Allmendinger \& M. Tewdwr-Jones (Eds.), Planning futures. New directions for planning theory (pp. 21-43). London and New York, NY: Routledge.

Healey, P. (1992). A planner's day: Knowledge and action in communicative practice. Journal of the American Planning Association, 58(1), 9-20. https://doi.org/10. 1080/01944369208975531

Healey, P. (1997). Collaborative planning: Shaping places in fragmented societies. Basingstoke: Macmillan.

Healey, P. (2003). Collaborative planning in perspective. Planning Theory, 2(2), 101-123.

Hoch, C. (1994). What planners do: Power, politics and persuasion. Chicago, IL: American Planning Association.

Howe, E., \& Kaufman, J. (1979). The ethics of contemporary American planners. Journal of the American Plan- ning Association, 45(3), 243-255.

Innes, J. E. (1995). Planning theory's emerging paradigm: Communicative action and interactive practice. Journal of Planning Education and Research, 14(3), 183-189.

Knox, P. L., \& Masilola, C. O. (1990). Role orientations of third world urban planners. Environment and Planning B, 17(1), 9-22. https://doi.org/10.1068/ b170009

Krau, I. (2014). Stadt- und Raumplaner. Zum Wandel eines Berufsbildes [Urban and spatial planner. The change of a profession]. Raumforschung und Raumordnung, 72(4), 309-321. https://doi.org/10.1007/ s13147-014-0297-4

Krüger, T. (2013). AbsolventInnenbefragung 2011 für die Studiengänge der Stadtplanung in Hamburg 1983-2013 [2011 Survey of graduates for the study programs of urban planning in Hamburg 1983-2013]. In HafenCity Universität Hamburg, Studiengang Stadtplanung (Ed.), 30 Jahre Studium der Stadtplanung in Hamburg TUHH-HCU [30 years studying urban planning in Hamburg TUHH-HCU] (pp. 26-35). Hamburg: HafenCity Universität Hamburg.

Lamker, C. W. (2016). Unsicherheit und Komplexität in Planungsprozessen-Planungstheoretische Perspektiven auf Regionalplanung und Klimaanpassung [Uncertainty and complexity in planning processesPlanning theoretical perspectives on regional planning and climate adaptation]. Lemgo: Dorothea Rohn.

Lauria, M., \& Long, M. (2017). Planning experience and planners' ethics. Journal of the American Planning Association, 83(2), 202-220. https://doi.org/10.1080/ 01944363.2017 .1286946

Leschinski-Stechow, K., \& Seitz, J. (2015). AbsolventInnenbefragung 2015 [Graduate survey 2015]. Dortmund: School of Spatial Planning, TU Dortmund.

Levin-Keitel, M., Mölders, T., Othengrafen, F., \& Ibendorf, J. (2018). Sustainability transitions and the spatial interface: Developing conceptual perspectives. Sustainability, 10(6). https://doi.org/10.3390/ su10061880

Levin-Keitel, M., Othengrafen, F., \& Behrend, L. (2019). Stadtplanung als Disziplin. Alltag und Selbstverständnis von Planerinnen und Planern [Urban planning as a discipline. Daily business and self-image of planners]. Raumforschung und Raumordnung, 77(2), 1-16.

Liggett, H. (1996). Examining the planning practice conscious(ness). In S. Mandelbaum, L. Mazza, \& R. Burchell (Eds.), Explorations in planning theory (pp. 299-306). Rutgers: Centre for Urban Policy Research.

Loorbach, D., Frantzeskaki, N., \& Avelino, F. (2017). Sustainability transitions research: Transforming science and practice for societal change. Annual Review of Environment and Resources, 42(4), 599-626.

Low, N. (1991). Planning politics and the state. Sydney: Unwin Hyman.

Mandelbaum, S. (1996). Introduction: The talk of the 
community. In S. Mandelbaum, L. Mazza, \& R. Burchell (Eds.), Explorations in planning theory (pp. xi-xix). New Brunswick, NJ: Rutgers University.

McGuirk, P. M. (1995). Power and influence in urban planning: Community and property interests' participation in Dublin's planning system. Irish Geography, 28(1), 64-75. https://doi.org/10.1080/ 00750779509478679

Nevens, F., Frantzeskaki, N., Gorissen, L., \& Loorbach, D. (2013). Urban transition labs: Co-creating transformative action for sustainable cities. Journal of Cleaner Production, 50, 111-122.

Othengrafen, F., Levin-Keitel, M., \& Breier, D. C. (2019). Stadtplanung als interdisziplinäre Disziplin. Eine Bestandsaufnahme des Alltags von Planerinnen und Planern in deutschen Mittelstädten [Urban planning as an interdisciplinary discipline. An inventory of the daily business of planners in medium-sized German cities]. pnd/online, 2019(1), 2-12. Retrieved from http://www.planung-neu-denken.de/images/ stories/pnd/dokumente/1_2019/othengrafen\%20et \%20al.pdf

Pahl-Weber, E., \& Henckel, D. (2008). The planning system and planning terms in Germany: A glossary (Studies in Spatial Development No. 7). Hanover: Academy for Spatial Research and Planning. Retrieved from http://shop.arl-net.de/media/direct/pdf/ssd_7.pdf

Reckwitz, A. (2002). Toward a theory of social practices. A development in culturalist theorizing. European Journal of Social Theory, 5(2), 243-263.

Rotmans, J., Kemp, R., \& van Asselt, M. (2001). More evolution than revolution: Transition management in public policy. Foresight, 3(1), 15-31.

Sager, T. (2009). Responsibilities of theorists: The case of communicative planning theory. Progress in Planning, 72(1), 1-51.

Savini, F. (2019). Responsibility, polity, value: The (un)changing norms of planning practices. Planning Theory, 18(1), 58-81.

Savini, F., Majoor, S., \& Salet, W. (2015). Dilemmas of planning: Intervention, regulation, and investment. Planning Theory, 14(3), 296-315.

Schäpke, N., Singer-Brodowski, M., Stelzer, F., Bergmann, M., \& Lang, D. J. (2015). Creating space for change: Real-world laboratories for sustainability transformations. The case of Baden-Württemberg. GAIA, 24(4), 281-283.

Schatzki, T. R. (2001). Introduction: Practice theory. In T. R. Schatzki, K. Knorr Cetina, \& E. von Savigny (Eds.), The practice turn in contemporary theory (pp. 10-23). London: Routledge.

Schatzki, T. R. (2002). The site of the social. Philadelphia, PA: The Pennsylvania State University.

Schatzki, T. R. (2016). Praxistheorie als flache Ontologie
[Practice theory as flat ontology]. In H. Schäfer (Ed.), Praxistheorie. Ein soziologisches Forschungsprogramm [Practice theory. A sociological research programme] (pp. 29-44). Bielefeld: transcript.

Schmitt, G. (2010). StadtplanerInnen zwischen den Stühlen? Beobachtungen eines Berufsfeldes und Folgerungen für die Ausbildung [Urban planners between the chairs? Observations of the profession and consequences for education]. In U. Altrock, S. Huning, T. Kuder, \& H. Nuissl (Eds.), Zwanzig Jahre Planung im vereinigten Deutschland [Twenty years of planning in a united Germany] (pp. 327-346). Kassel: Fachgebiet Stadtumbau/Stadterneuerung, Kassel University.

Schön, D. A. (1982). Some of what a planner knows. A case study of knowing-in-practice. Journal of the American Planning Association, 48(3), 351-364. https://doi.org/10.1080/01944368208976184

Schön, D. A. (1983). The reflective practitioner: How professionals think in action. New York, NY: Basic Books.

Schwartz, S. H. (2012). An overview of the Schwartz theory of basic values. Online Readings in Psychology and Culture, 2(1). http://dx.doi.org/10.9707/23070919.1116

Shove, E., Pantzar, M., \& Watson, M. (2012). The dynamics of social practice. Everyday life and how it changes. London: Sage.

Swidler, A. (2001). What anchors cultural practices. In T. R. Schatzki, K. Knorr Cetina, \& E. von Savigny (Eds.), The practice turn in contemporary theory (pp. 83-101). London: Routledge.

Vickers, S. G. (1968). Value systems and social process. New York, NY: Basic Books.

Vigar, G. (2012). Planning and professionalism: Knowledge, judgement and expertise in English planning. Planning Theory, 11(4), 361-378. http://dx.doi.org/ 10.1177/1473095212439993

Völkl, K., \& Korb, C. (2018). Deskriptive Statistik. Eine Einführung für Politikwissenschaftlerinnen und Politikwissenschaftler [Descriptive statistics. An introduction for political scientists]. Wiesbaden: Springer.

Watson, V. (2002). Do we learn from planning practice? The contribution of the practice movement to planning theory. Journal of Planning Education and Research, 22(2), 178-187.

Zimmermann, K. (2017). Praxisansätze in der planungswissenschaftlichen Diskussion [Practice theories in the field of planning science]. Nachrichten der $A R L, 47(1), 14-16$.

Zlonicky, P. (2009). Zum Selbstverständnis der Stadtplaner [On the self-image of urban planners]. Paper presented at "NEUSTART: Die Zukunft der Stadtplanung. Aufgabe-Profession-Lehre" [Re-start: The future of urban planning. Task-Profession-Teaching], Aachen. 


\section{About the Authors}

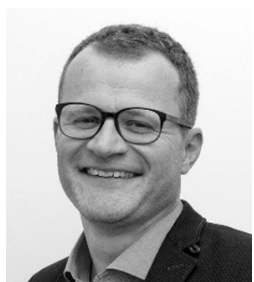

Frank Othengrafen is Professor of Urban and Regional Planning at the Faculty for Spatial Planning at TU Dortmund. Before his appointment at TU Dortmund he was Associate Professor for Regional Planning and Governance at Leibniz Universität Hannover (2013-2019) and Visiting Professor for Regional Planning and Development at HafenCity Universität Hamburg (2010-2012). He has research and teaching experience in the fields of urban and regional planning and governance, planning theory, international comparative planning, and planning culture.

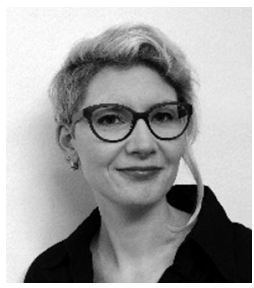

Meike Levin-Keitel is Head of the Junior Research Group "MoveMe-For a Socio-Spatial Transformation towards Sustainable Mobility Behaviour" at TU Dortmund. Her main research interest covers planning approaches in theory and practice including questioning what urban and regional planning is all about, how planning is transferred in scientific and theoretical approaches and what this implies for the study of planning. Her contemporary focus is, furthermore, how planning is able to contribute to current societal transformation and challenges. 